\title{
Dampak Reformasi Birokrasi pada Perubahan Budaya Organisasi di Perwakilan BPKP Provinsi DKI Jakarta
}

\author{
Nina Aridhona \\ Program Pascasarjana Manajemen dan Bisnis \\ Institut Pertanian Bogor \\ Gedung MB-IPB, Jl. Raya Pajajaran, Bogor 16151 \\ e-mail : adriyudo@yahoo.com \\ Lukman M. Baga \\ Departemen Agribisnis, Fakultas Ekonomi dan Manajemen \\ Institut Pertanian Bogor \\ Kampus IPB Darmaga 16680 \\ M. Joko Affandi \\ Program Pascasarjana Manajemen dan Bisnis \\ Institut Pertanian Bogor \\ Gedung MB-IPB, Jl. Raya Pajajaran, Bogor 16151
}

\begin{abstract}
Various changes in the strategic environment have forced the public sector to make bureaucratic reform that should have consequences on changing the bureaucratic culture in the public sectorsto be more externally oriented culture. Financial and Development Supervisory Agency (BPKP) is an internal control government agency that should change the organizational culture. The needs for externally oriented culture was now even stronger in line with the shift in the role from watchdog to become inhouse consultant. Therefore, this study aims to analyze organizational culture changes and identify the factors that cause or inhibit changes. This study used competing values framework, a method that is able to capture the changes of organizational cultures, both large and direction. The research result showed that organizational culture has been transformed from hierarchy culture to market culture. These changes indicated the organizational culture has been changed in accordance with the concept of bureaucratic reform. However, the changes in organizational culture were not significant. Employee resistance and the policy of change that is not the same in all aspects of organizational were known as the factors inhibiting organizational culture changes.

Key word: bureaucratic reform, competing values framework, organizational change, organizational culture, public sector
\end{abstract}

\begin{abstract}
ABSTRAK
Berbagai perubahan lingkungan strategik telah mendorong sektor publik untuk melakukan reformasi birokrasi yang seharusnya memberikan dampak pada perubahan budaya organisasi sektor publik yang selama ini cenderung birokratis menjadi budaya yang lebih berorientasi eksternal. Badan Pengawasan Keuangan dan Pembangunan (BPKP) merupakan lembaga pengawasan internal pemerintah yang seharusnya mengalami perubahan budaya organisasi. Kebutuhan budaya organsiasi yang berorientasi eksternal semakin menguat seiring terjadinya pergeseran peran dari watchdog menjadi in house consultant. Oleh karena itu, penelitian ini bertujuan untuk melihat bagaimana perubahan budaya organisasi yang terjadi dan mengindetifikasi faktor yang menyebabkan atau menghambat perubahan. Penelitian ini menggunakan metode competing values framework, yaitu pendekatan budaya organisasi
\end{abstract}


yang dapat menangkap perubahan budaya organisasi baik besar dan arah perubahannya. Hasil penelitian menunjukkan bahwa budaya organisasi telah berubah dari budaya hierarchy menjadi budaya market yang artinya telah berubah sesuai dengan konsep reformasi birokrasi. Namun, perubahan tersebut tampak belum optimal. Adanya resistensi pegawai dan belum seragamnya kebijakan perubahan pada semua aspek dalam organisasi menjadi faktor penyebab lambatnya perubahan.

Kata Kunci: reformasi birokrasi, competing values framework, perubahan organisasi, budaya organisasi, sektor publik

\section{Pendahuluan}

Menyusul terjadinya krisis multidimensi yang melanda Indonesia pada tahun 1998, kepercayaan publik terhadap kinerja pemerintah semakin menurun. Menurunnya tingkat kepercayaan masyarakat berimbas pada tuntutan akan terwujudnya good governance yang bebas korupsi, kolusi dan nepotisme (KKN). Sebagai respon atas tuntutan tersebut, pemerintah melakukan perubahan di sektor publik yang dikenal dengan reformasi birokrasi. Reformasi birokrasi yang dilaksanakan di Indonesia merupakan adopsi dari konsep New Public Management (NPM) yang sebelumnya telah banyak berkembang dan diimplementasikan di berbagai negara maju seperti seperti Inggris, Australia dan New Zeland (Jones dan Kettl 2004; Larbi 2003). NPM merupakan konsep reformasi birokrasi yang mengadopsi prinsip-prinsip dan manajemen sektor swasta yang ditujukan untuk menjadikan kinerja sektor publik lebih ekonomis, efisien dan efektif (Hood 1991; Brown et al. 2003).

Membuat perubahan pada organisasi sektor publik memang tidak semudah pada sektor swasta. Adanya perbedaan kondisi dan karakteristik lingkungan eksternal maupun internal antara sektor publik dan sektor swasta menjadi penyebab sulitnya membuat perubahan di sektor publik (Schraeder et al. 2005; Greasly 2008). Osborne dan Gaebler (1992) menyatakan bahwa salah satu kendala dalam reformasi birokrasi adalah budaya organisasi di sektor publik. Stigma negatif tentang budaya organisasi sektor publik yang cenderung lebih birokratis dan taat pada aturan dan regulasi merupakan alasan kuat bahwa perubahan budaya organisasi menjadi salah satu ukuran outcomes dari keberhasilan reformasi birokrasi. Hendarto (2012) menyebutkan bahwa kecenderungan budaya birokratis dan taat pada aturan sangat dipengaruhi oleh paradigma bahwa aparatur pemerintah hanya sebagai pengelola administrasi negara dan bukan memberikan pelayanan kepada masyarakat.

Beberapa penelitian tentang reformasi birokrasi pernah dilakukan di Indonesia. Salah satu penelitian tersebut dilakukan oleh Subagio (2012), yang melakukan penelitian untuk menganalisis penerapan reformasi birokrasi ditinjau dari aspek kelembagaan, ketatalaksanaan, sumber daya manusia (SDM), akuntabilitas dan pelayanan umum. Penelitian lain dilakukan oleh Prawirodirjo (2007) yang melakukan analisis pengaruh perubahan organisasi dan budaya organisasi terhadap kepuasan dan kinerja pegawai. Namun hingga saat ini, berbagai penelitian tersebut belum ada yang secara spesifik menyinggung aspek perubahan budaya organisasi setelah dilakukannya reformasi birokrasi. Padahal berbagai penelitian membuktikan bahwa kinerja organisasi sangat dipengaruhi oleh beberapa faktor yang salah satunya adalah budaya organisasi. Besarnya peran budaya organisasi pada peningkatan kinerja telah dibuktikan dalam berbagai penelitian (Aluko 2003; Ojo 2010; Shahzad et al. 2012; Uddin et al. 2013). Bahkan hasil penelitian oleh Carmeli dan Tishler (2004) menemukan 
bahwa diantara lima elemen tidak berwujud yaitu kemampuan manajerial, modal manusia, reputasi organisasi, pengawasan internal dan hubungan kerja, budaya organisasi menjadi salah satu elemen terpenting yang memiliki dampak signifikan terhadap kinerja organisasi. Pemahaman terhadap budaya organisasi dapat membantu organisasi untuk lebih mengenal karakteristik fundamental organisasi, sehingga mampu menentukan kebijakan-kebijakan yang tepat dalam rangka meningkatkan kinerja organiasi.

Osborne dan Plastrik (1997) menyatakan bahwa pada dasarnya reformasi birokrasi seharusnya dapat memberikan konsekuensi pada terjadinya perubahan budaya organisasi. Budaya dengan mindset birokratis yang telah melekat pada sektor publik di Indonesia sudah seharusnya berubah (Muhammad 2008). Perubahan yang diharapkan adalah perubahan budaya organisasi yang lebih berorientasi eksternal. Menurut Asropi (2008), budaya inovatif harus menjadi nilai utama dalam budaya birokrasi di Indonesia. Hal ini sejalan dengan pernyataan Osborne dan Gaebler (1992) yang menyatakan bahwa budaya organisasi yang dibutuhkan di sektor publik adalah budaya sesuai tujuan reformasi birokrasi yaitu pemerintahan yang berkewirausahaan, berorientasi pada hasil dan berorientasi pada pemenuhan kebutuhan pemangku kepentingan (stakeholder).

Namun demikian, konsekuensi terjadinya perubahan budaya organisasi setelah reformasi birokrasi masih perlu dibuktikan lebih lanjut karena perubahan budaya organisasi pada sektor publik tentu tidak semudah pada sektor swasta. Sulitnya membuat perubahan budaya organisasi di sektor publik telah dibuktikan dalam penelitian Parker dan Bradley (2001) yang menemukan bahwa setelah reformasi birokrasi, hanya terdapat satu diantara enam organisasi sektor publik di Quensland yang memiliki kecenderungan budaya organisasi sesuai dengan konsep NPM. Budaya pada organisasi lainnya masih mencerminkan budaya hierarchy atau budaya yang masih kental dengan model administrasi publik tradisional atau model birokrasi tradisional. Namun sebaliknya, penelitian yang dilakukan oleh Phookpan (2012) pada sektor publik di Thailand menemukan bahwa setelah reformasi birokrasi, budaya organisasi cenderung lebih berorientasi eksternal. Hal ini menunjukkan bahwa walaupun telah menjadi budaya yang telah berakar, budaya sektor publik yang cenderung berorientasi internal dimungkinkan untuk mengalami perubahan ke arah budaya yang lebih berorientasi eksternal.

Sebagaimana organisasi sektor publik lainnya, Badan Pengawasan Keuangan dan Pembangunan (BPKP) merupakan organisasi sektor publik yang melaksanakan reformasi birokrasi. Reformasi birokrasi di BPKP diharapkan juga dapat memberikan konsekuensi terhadap perubahan budaya organisasi. Kebutuhan terjadinya perubahan budaya organisasi di BPKP semakin meningkat seiring dengan terjadinya perubahan peran BPKP dari watchdog menjadi in house consultant. Perubahan peran ini menyebabkan kegiatan pengawasan yang sebelumnya banyak bersifat represif dan ditujukan untuk memberikan keyakinan bahwa obyek pengawasan telah menjalankan seluruh kebijakan dan program yang telah ditetapkan, kini lebih banyak bersifat preventif dan ditujukan untuk memberikan early warning, meningkatkan efektivitas manajemen risiko, dan memelihara serta meningkatkan mutu tata kelola stakeholder. Kegiatan pengawasan lebih banyak ditujukan untuk mengawal stakeholder agar berada 
pada jalur yang tepat dan memberikan saran perbaikan kepada stakeholder untuk melakukan perbaikan atas terjadinya kesalahan. Hal ini merupakan penegasan kembali bahwa fungsi organisasi pengawasan internal pemerintah sebagaimana disebutkan dalam CIIA (2014) adalah lebih diarahkan untuk melakukan tindakan preventif terhadap terjadinya penyimpangan.

Dalam rangka menjalankan peran dan fungsi sebagai organisasi pengawasan internal pemerintah, budaya organisasi yang berorientasi internal diharapkan menurun dan digantikan dengan budaya organisasi yang lebih berorientasi eksternal sesuai dengan konsep reformasi birokrasi. Oleh karena itu, penelitian ini bertujuan untuk menilai bagaimana perubahan budaya organisasi yang terjadi setelah reformasi birokrasi dan mengidentifikasi faktor yang menyebabkan atau menghambat terjadinya perubahan. Perubahan budaya organisasi dapat dijadikan salah satu indikator keberhasilan atau outcomes pelaksanaan reformasi birokrasi. Penelitian difokuskan pada perwakilan Badan Pengawasan Keuangan dan Pembangunan (BPKP) Provinsi DKI Jakarta karena Perwakilan BPKP DKI Jakarta merupakan salah satu instansi vertikal BPKP yang terbesar di Indonesia.

\section{Metode Penelitian}

Metode penelitian yang digunakan untuk menilai perubahan budaya organisasi adalah competing values framework. Pendekatan competing values framework merupakan pendekatan budaya organisasi yang memiliki asumsi dasar bahwa suatu organisasi memiliki beberapa budaya organisasi sekaligus (Ramachandran 2010). Organisasi yang menekankan pada budaya organisasi tertentu, pasti tetap memiliki tipe budaya organisasi lain yang berlawanan. Pendekatan ini melibatkan dua dimensi yang saling bertentangan, yaitu 1) flexibility and discretion dengan stability and control dan 2) internal focus and integration dengan external focus and differentiation. Dimensi tersebut membagi tipe budaya organisasi dalam empat kuadran yaitu 1) clan, yaitu budaya kekeluargaan; 2) adhorcracy yaitu budaya inovatif dan kreatif; 3) market yaitu budaya yang berorientasi pada hasil, dan 4) hierarchy yaitu budaya yang menekankan stabilitas, kontrol dan ketaatan pada peraturan. Sebagaimana dijelaskan dalam pendahuluan, reformasi birokrasi diarahkan untuk mewujudkan pemerintahan yang berkewirausahaan, berorientasi pada hasil dan berorientasi pada pemenuhan kebutuhan stakeholder. Dikaitkan dengan metode competing value framework, perubahan budaya yang diharapkan terjadi adalah perubahan budaya organisasi yang lebih berorientasi eksternal yang dalam hal ini dapat diwakili oleh budaya market atau budaya adhorcracy. Model competing value framework terlihat pada Gambar 1.

Dalam penelitian ini, kuesioner didistribusikan kepada 84 responden dari total populasi sebanyak 107 auditor dengan teknik accidental sampling. Responden merupakan auditor yang telah bekerja selama lebih dari 10 tahun. Dengan masa kerja lebih dari 10 tahun, auditor dianggap mampu merasakan perbedaan budaya organisasi, baik sebelum maupun setelah reformasi birokrasi. Kuesioner yang digunakan dalam penelitian ini adalah Organizational Culture Asessment Instrument (OCAl) yang terdiri dari 6 sub peubah yaitu 1) karakter dominan; 2) kepemimpinan; 3) manajemen sumber daya manusia; 4) penguat ikatan organisasi; 5) penekanan 
strategi, dan 6) kriteria keberhasilan. Pada tiap-tiap sub peubah terdapat empat alternatif pertanyaan yang masing-masing menggambarkan budaya clan, adhorcracy, market dan hierarchy.

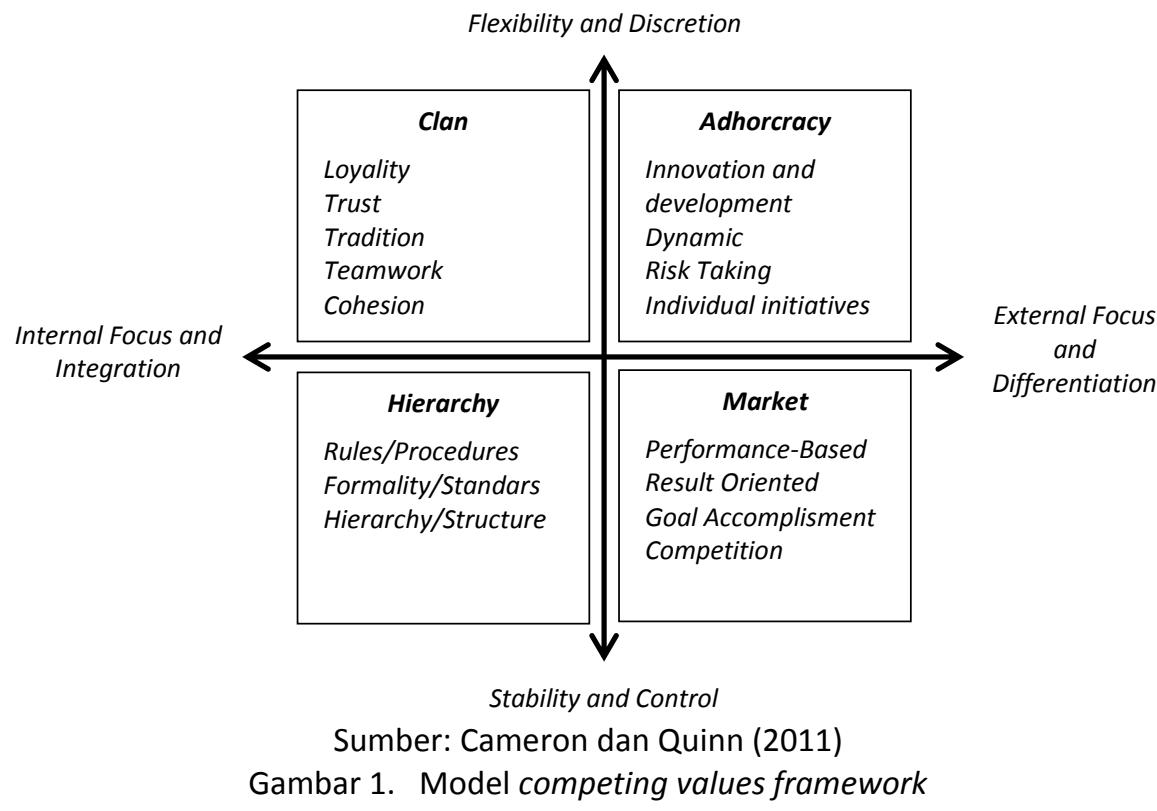

Dalam kuesioner tersebut, responden diminta untuk mendistribusikan 100 poin pada empat alternatif pertanyaan pada tiap sub peubah. Nilai lebih tinggi diberikan untuk alternatif budaya yang sesuai dengan kondisi sebenarnya dan nilai lebih rendah diberikan untuk alternatif budaya yang paling tidak sesuai dengan kondisi sebenarnya. Pemberian nilai dilakukan pada dua kolom, yaitu kolom sebelum reformasi birokrasi dan kolom setelah reformasi birokrasi. Data yang terkumpul melalui kuesioner selanjutkan diolah dengan metode statistik deskriptif dengan mencari rataan (mean) dari peubah budaya organisasi sebelum dan setelah reformasi birokrasi untuk keempat tipe budaya organisasi, yaitu clan, adhorcracy, market dan hierarchy. Selanjutnya hasil perhitungan dituangkan dalam grafik competing value framework.

Dari hasil pengolahan data, analisis yang dilakukan adalah menilai budaya organisasi yang paling dominan dalam organisasi baik sebelum maupun setelah reformasi birokrasi dan melihat kecenderungan perubahan budaya organisasi. Dalam penelitian ini, budaya dikatakan memiliki ciri yang kuat apabila memiliki selisih lebih dari lima poin dengan budaya lain. Perubahan budaya organisasi dinilai signifikan apabila mengalami peningkatan lebih dari lima poin (Cameron dan Quinn 2011). Setelah itu, dilakukan analisis kongruensi atau kesesuaian arah perubahan budaya organisasi pada enam sub peubah budaya organisasi. Wawancara juga dilakukan untuk memberikan gambaran mengenai faktor-faktor yang menghambat atau mempercepat terjadinya perubahan budaya organisasi.

\section{Hasil dan Pembahasan}

Sebagaimana telah disebutkan pada pendahuluan, budaya organisasi diharapkan mengalami perubahan ke arah yang lebih berorientasi eksternal. Dari hasil pengolahan 
data budaya organisasi secara umum, tampak bahwa kecenderungan budaya organisasi sebelum reformasi birokrasi adalah budaya hierarchy dengan skor 28.7. Hal ini mencerminkan bahwa budaya organisasi sebelum reformasi birokrasi lebih menekankan pada terciptanya stabilitas dan kontrol. Ditemukannya budaya hierarchy sebagai budaya paling dominan memperlihatkan bahwa organisasi masih dipengaruhi oleh model birokrasi tradisional ala Weber (Hughes 2003). Namun dilihat dari perbedaan skor, pada dasarnya ciri budaya hierarchy tidak terlalu kuat karena hanya memiliki selisih skor 2.6 dengan budaya market.

Setelah reformasi birokrasi, data menunjukkan bahwa budaya organisasi mengalami pergeseran. Pergeseran terjadi pada peningkatan budaya market sebesar 1.4. Pergeseran tersebut menyebabkan budaya hierarchy yang sebelumnya menjadi budaya paling dominan digantikan oleh budaya market. Pergeseran budaya organisasi ke arah yang berorientasi eksternal yaitu market menunjukkan bahwa perubahan budaya organisasi telah sesuai dengan arah yang diharapkan dan konsep reformasi birokrasi (Osborne dan Gaebler 1992; Larbi 2003; Muhammad 2008).

Tabel 1. Skor rataan budaya organisasi

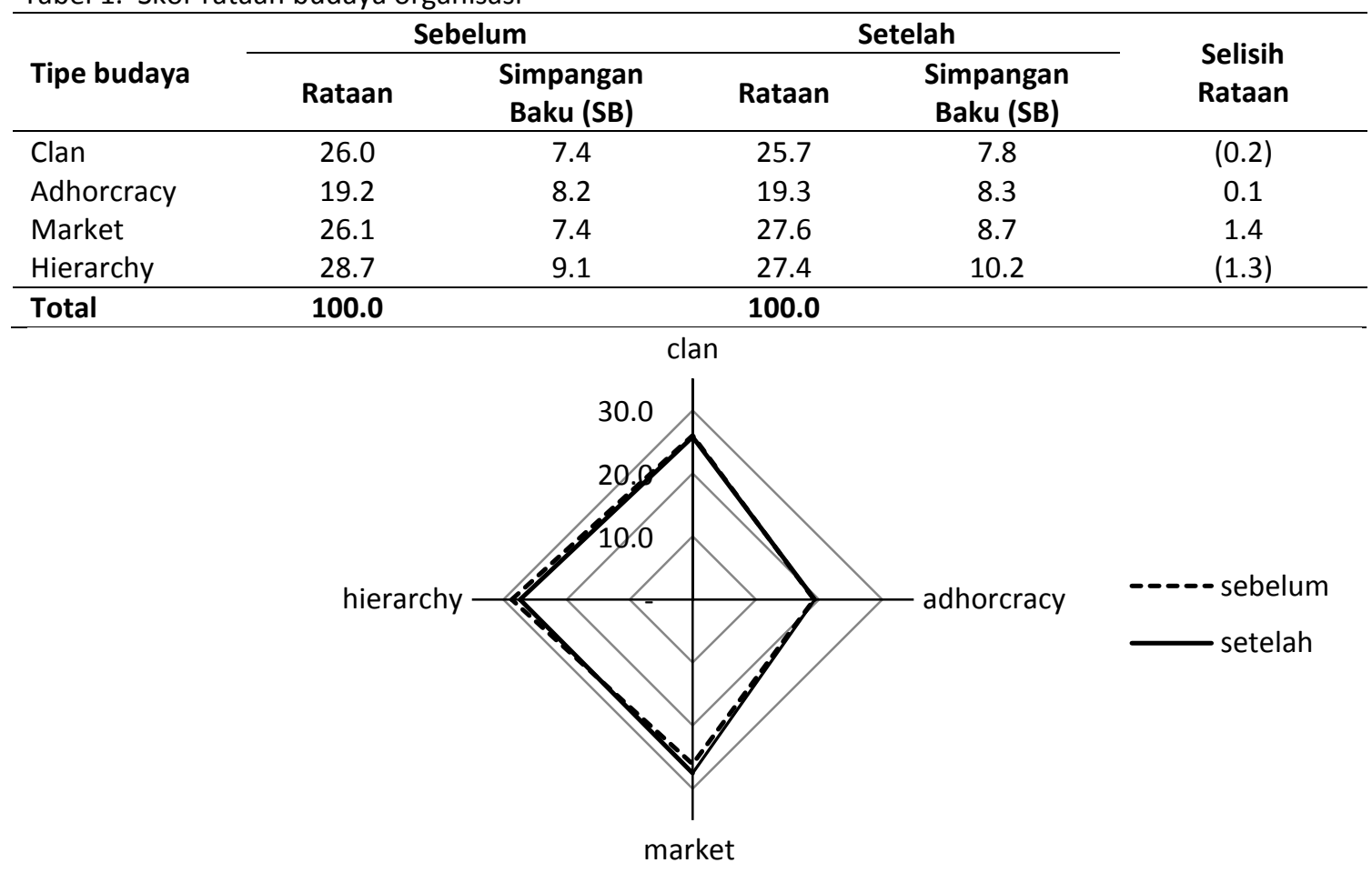

Gambar 2. Profil perubahan budaya organisasi

Faktor kepemimpinan merupakan salah satu fakor yang berperan dalam mengubah budaya organisasi dari budaya hierarchy menjadi budaya market. Menurut hasil wawancara, faktor kepemimpinan tidak lepas dari kebijakan pemilihan kepemimpinan yang merupakan bagian dari program penataan SDM aparatur. Kebijakan ini memastikan bahwa pemangku jabatan memiliki visi dan misi yang sejalan dengan tujuan organisasi dan memenuhi kualifikasi yang dipersyaratakan untuk menduduki jabatannya. Peran kepemimpinan sejalan dengan data kuantitatif yang 
menunjukkan bahwa sub peubah kepemimpinan merupakan sub budaya organisasi yang mengalami kenaikan budaya market relatif besar dibandingkan dengan kenaikan pada sub peubah lainnya. Kepemimpinan yang sebelum reformasi birokrasi telah ditunjukkan dalam bentuk mendorong bawahan untuk bekerja dengan sungguhsungguh, sepenuh hati, agresif, dan berorientasi pada hasil kini bertambah kuat. Kenaikan budaya market pada sub peubah kepemimpinan mengindikasikan bahwa pada dasarnya organisasi telah menaruh perhatian pada pentingnya peran kepemimpinan sebagai agen perubahan (Simpson dan Beeby 1993; Cole et al. 2006). Organisasi menyadari bahwa dukungan manajerial yang cukup sangat berpengaruh terhadap perubahan budaya organisasi (Parker dan Bradley 2001).

Kebijakan rightsizing merupakan kebijakan lain yang berdampak pada perubahan budaya organisasi. Rightsizing yang ditujukan untuk menata organisasi pemerintahan menjadi lebih tepat ukuran dan fungsi menyebabkan struktur organisasi lebih fungsional. Pemangkasan rantai birokrasi menjadi lebih fungsional berdampak pada semakin efisiennya proses review berjenjang atas pelaksanaan pekerjaan karena proses review lebih banyak dilakukan dalam jenjang profesi. Penyempurnaan struktur organisasi yang lebih fungsional menyebabkan perubahan integrasi dan koordinasi sehingga berpengaruh pada kemudahan komunikasi dan arus informasi dalam organisasi. Organisasi yang lebih fungsional menyebabkan anggota organisasi lebih bebas untuk mengkontrol kegiatan sendiri sehingga memicu terjadinya perubahan budaya organisasi yang lebih berorientasi pada hasil.

Kebijakan survei kepuasan pelanggan yang dilakukan pada setiap akhir penugasan juga ditengarai menjadi faktor bergesernya budaya organisasi menjadi budaya market. Kebijakan survei kepuasan pelanggan merupakan cerminan bahwa kriteria keberhasilan organisasi adalah kepuasan stakeholder. Kebijakan ini mendorong pegawai untuk lebih berorientasi eksternal dan mementingkan kepentingan stakeholder. Hasil ini mendukung penilaian data kuantitatif yang memperlihatkan bahwa pada sub peubah kriteria keberhasilan, budaya yang dominan telah berubah dari budaya hierarchy menjadi budaya market. Kenaikan budaya market bahkan menjadi kenaikan yang paling tinggi diantara sub peubah lainnya. Skor rataan sub peubah budaya organisasi baik sebelum reformasi birokrasi, setelah reformasi birokrasi, dan perubahan skornya berturut-turut diperlihatkan dalam Tabel 2, Tabel 3, dan Tabel 4.

Tabel 2. Skor rataan sub peubah budaya sebelum reformasi birokrasi

\begin{tabular}{lcccccccc}
\hline & \multicolumn{2}{c}{ Clan } & \multicolumn{3}{c}{ Adhorcracy } & \multicolumn{2}{c}{ Market } & \multicolumn{2}{c}{ Hierarchy } \\
& Rataan & SB & Rataan & SB & Rataan & SB & Rataan & SB \\
\hline Karakter dominan & 26.6 & 7.6 & 17.8 & 7.9 & 28.6 & 8.0 & 27.0 & 9.6 \\
Kepemimpinan & 25.1 & 7.6 & 18.3 & 8.0 & 28.6 & 7.3 & 28.0 & 7.6 \\
Manajemen SDM & 28.1 & 7.8 & 19.6 & 9.6 & 23.6 & 8.1 & 28.8 & 9.2 \\
Penguat ikatan organisasi & 25.7 & 6.8 & 20.6 & 7.3 & 25.7 & 6.0 & 28.0 & 7.7 \\
Penekanan strategi & 24.8 & 7.2 & 19.1 & 7.3 & 23.9 & 6.3 & 32.2 & 10.7 \\
Kriteria keberhasilan & 25.7 & 6.9 & 19.8 & 8.7 & 26.5 & 6.7 & 28.0 & 8.8 \\
\hline
\end{tabular}


Tabel 3. Skor rataan sub peubah budaya setelah reformasi birokrasi

\begin{tabular}{lcccccccc}
\hline & \multicolumn{2}{c}{ Clan } & \multicolumn{2}{c}{ Adhorcracy } & \multicolumn{2}{c}{ Market } & \multicolumn{2}{c}{ Hierarchy } \\
& Rataan & SB & Rataan & SB & Rataan & SB & Rataan & SB \\
\hline Karakter dominan & 26.6 & 9.0 & 17.1 & 7.7 & 29.8 & 9.3 & 26.5 & 10.1 \\
Kepemimpinan & 24.0 & 7.1 & 19.1 & 8.5 & 30.4 & 7.8 & 26.6 & 8.6 \\
Manajemen SDM & 27.8 & 7.8 & 19.2 & 8.3 & 25.0 & 8.6 & 28.0 & 9.7 \\
Penguat ikatan organisasi & 24.8 & 7.4 & 20.6 & 7.7 & 27.3 & 7.5 & 27.3 & 9.1 \\
Penekanan strategi & 25.6 & 7.3 & 21.0 & 8.5 & 24.0 & 8.0 & 29.4 & 13.3 \\
Kriteria keberhasilan & 25.7 & 7.7 & 19.0 & 8.9 & 28.9 & 9.1 & 26.4 & 9.7 \\
\hline
\end{tabular}

Tabel 4. Skor perubahan rataan sub peubah budaya organisasi

\begin{tabular}{lcccc}
\hline & Clan & Adhorcracy & market & Hierarchy \\
\hline Karakter dominan & $(0.0)$ & $(0.7)$ & 1.2 & $(0.5)$ \\
Kepemimpinan & $(1.1)$ & 0.7 & 1.8 & $(1.4)$ \\
Manajemen SDM & $(0.3)$ & $(0.3)$ & 1.4 & $(0.8)$ \\
Penguat ikatan organisasi & $(0.9)$ & $(0.1)$ & 1.6 & $(0.7)$ \\
Penekanan strategi & 0.8 & 1.9 & 0.1 & $(2.8)$ \\
Kriteria keberhasilan & $(0.0)$ & $(0.8)$ & 2.4 & $(1.6)$ \\
\hline
\end{tabular}

Sebagaimana dijelaskan sebelumnya, beragam faktor pendorong terjadinya perubahan budaya organisasi tidak lepas dari kebijakan dan strategi reformasi birokrasi. Osborne dan Plastrik (1997) menyatakan bahwa budaya organisasi dipengaruhi oleh tujuan organisasi, sistem insentif, sistem pertanggungjawaban, dan sistem kekuasan. Perubahan pada unsur tersebut menyebabkan terjadinya perubahan budaya organisasi. Kebijakan pemilihan kepemimpinan merupakan bagian dari perubahan sistem insentif. Kebijakan tersebut memberikan konsekuensi terhadap persaingan pegawai, sehingga hanya pegawai yang memenuhi kualifikasi tertentu yang dapat menduduki jabatan pimpinan dalam organisasi. Rightsizing merupakan bagian dari strategi kontrol yang berkaitan dengan perubahan sistem kekuasaan. Rightsizing menyebabkan proses review menjadi semakin efisien. Sedangkan kebijakan survey kepuasan pelanggan merupakan strategi yang berhubungan dengan stakeholder. Strategi yang diarahkan untuk menciptakan informasi tentang kepuasan pelanggan terhadap pelayanan merupakan perubahan sistem pertanggungjawaban. Organisasi tampak telah menitikberatkan bahwa pertanggungjawaban penugasan adalah kepada stakeholder. Faktor-faktor tersebut merupakan bukti bahwa kebijakan reformasi birokrasi pada dasarnya memberikan konsekuensi pada terjadinya perubahan budaya organisasi sebagaimana diungkapkan Osborne dan Plastrik (1997). Hasil ini sekaligus memperkuat hasil penelitian Phookpan (2012) pada organisasi sektor publik di Thailand yang menemukan bahwa telah terjadi perubahan budaya organisasi menjadi berorientasi eksternal setelah dilakukan reformasi birokrasi.

Namun di sisi lain, perubahan tersebut terlihat masih berjalan lambat. Menurut Cameron and Quinn (2011), perubahan dapat dikatakan signifikan apabila memiliki skor perubahan lebih dari lima poin. Kenaikan budaya market yang berkisar antara 1.2 sampai dengan 2.4 merupakan kenaikan yang relatif rendah. Budaya hierarchy sebelum reformasi birokrasi yang tidak begitu dominan seharusnya menjadikan perubahan budaya organisasi lebih mudah terjadi. Berdasarkan hasil wawancara ditemukan bahwa belum adanya keseragaman persepsi antara manajemen dan pegawai terkait kebijakan manajemen SDM pada beberapa pegawai merupakan faktor 
penghambat terjadinya perubahan. Penataan pola karir berbasis kompetensi yang yang seharusnya ditujukan untuk meningkatkan budaya kompetisi dan budaya pegawai untuk lebih berorientasi pada hasil dan pencapaian target justru menurunkan motivasi beberapa pegawai. Bagi beberapa pegawai, kebijakan tersebut justru dianggap sebagai kebijakan yang kaku dan menghambat pegawai. Hal ini menunjukkan bahwa walaupun secara umum kebijakan organisasi mampu mengubah budaya organisasi, faktor individu tetap memiliki berpengaruh yang relevan pada keefektifan kebijakan yang diterapkan. Hal ini juga seakan menguatkan pernyataan bahwa karakteristik internal merupakan salah satu penghambat sulitnya membuat perubahan pada organisasi sektor publik (Schraeder et al. 2005; Greasly et al. 2008). Hambatan belum adanya keseragaman persepsi antara manajemen dan beberapa pegawai terkait kebijakan manajemen SDM terlihat dari data kuantiatif yang menunjukkan bahwa budaya organisasi yang dominan pada sub peubah manajemen SDM masih tetap budaya hierarchy.

Secara umum, belum optimalnya peningkatan budaya market mengindikasikan bahwa masih diperlukan upaya peningkatan perubahan budaya organisasi. Dominasi budaya hierarchy pada manajemen SDM yang disebabkan masih adanya perbedaan persepsi tentang manajemen SDM memperlihatkan bahwa hambatan perubahan disebabkan oleh faktor individu atau adanya resistensi pegawai. Walaupun secara natural kebijakan reformasi berperan dalam mengubah budaya organisasi (Osborne dan Plastrik 1997), namun perubahan budaya organisasi pada akhirnya tergantung pada penerapan perilaku individu dalam organisasi dan konsistensi penerapan nilai atau budaya tersebut (Cameron dan Quinn 2011). Kepemimpinan merupakan faktor yang berperan penting dalam perubahan perilaku tersebut. Kepemimpinan yang pada dasarnya telah berkontribusi pada peningkatan budaya market tampaknya masih harus menjadi perhatian organisasi. Kemampuan manajerial sebagai agen perubahan terutama pada pimpinan yang menjalankan fungsi manajemen sumber daya manusia (SDM) masih perlu ditingkatkan. Pemimpin pada fungsi manajemen SDM harus mampu memberikan energi, memberikan motivasi dan inspirasi bagi pegawai untuk lebih proaktif, berusaha lebih keras, dan bekerja bersungguh-sungguh dan menekan-kan pada kepentingan stakeholder. Pimpinan pada fungsi manajemen SDM harus mampu menjadi agen perubahan untuk menginternalisasi budaya baru. Dalam proses internalisasi budaya baru, pimpinan pada fungsi manajemen SDM harus mampu menjalin komunikasi yang efektif dengan pegawai sehingga dapat membangun kesamaan persepsi, komitmen, serta keterlibatan semua pegawai dalam pelaksanaan program dan kegiatan reformasi birokrasi.

Dari aspek kongruensi, budaya organisasi setelah reformasi birokrasi tampak belum sepenuhnya kongruen. Kenaikan budaya marketdan penurunan budaya hierarchy memang telah terjadi secara seragam pada seluruh sub peubah budaya organisasi, namun pada sub peubah manajemen SDM dan penekanan strategi, budaya organisasi masih didominasi oleh budaya hierarchy. Khususnya untuk sub peubah penekanan strategi, selisih antara budaya hierarchy dan budaya market masih lebih dari lima poin, yang artinya dominasi budaya hierarchy masih cukup kuat. Organisasi tampak masih menekankan pada terciptanya solidaritas yang kuat, stabilitas yang tinggi, terciptanya efisiensi, kontrol kerja, dan kelancaran kegiatan operasional. 
Strategi tampak belum ditekankan untuk mendorong persaingan dan prestasi kerja, pencapaian target secara optimal, dan memenangkan persaingan. Disamping itu, berdasarkan data tampak bahwa perubahan pada sub peubah penekenan strategi lebih ditekankan ke arah budaya adhorcracy yaitu penciptaan tantangan dan peluang baru. Penekanan strategi ditemukan tidak searah dengan peningkatan pada lima sub peubah budaya lain yang semuanya terlihat diarahkan kepada perubahan budaya yang lebih berorientasi pada hasil.

Perubahan yang diarahkan pada budaya adhorcracy yaitu budaya yang menekankan pada penciptaan peluang dan tantangan baru pada dasarnya sejalan dengan konsep reformasi birokrasi. Namun penekanan pada budaya adhorcracy seharusnya dilakukan pada seluruh aspek atau sub peubah budaya organisasi. Cameron dan Quinn (2011) menyatakan bahwa pada umumnya, organisasi yang memiliki kinerja yang tinggi adalah organisasi yang memiliki budaya organisasi yang kongruen. Bahkan budaya organisasi yang tidak kongruen menyebabkan rasa tidak nyaman bagi anggota organisasi. Oleh karena itu, strategi perubahan hendaknya diupayakan lebih kongruen. Penetapan kebijakan perubahan ke arah budaya adhorcracy pada salah satu aspek tanpa diiringi dengan penetapan kebijakan yang kongruen pada aspek lainnya menyebabkan kebijakan kurang bermakna. Sebagai contoh, dari data yang diperoleh terlihat bahwa sub peubah penekanan strategi telah diarahkan pada budaya inovatif atau adhorcracy, namunpada sub peubah kriteria keberhasilan atau ukuran yang ditetapkan untuk menilai keberhasilan bukan dari aspek inovatif. Hal ini menyebabkan penekanan strategi yang telah ditetapkan kurang bermanfaat. Penilaian atau tindak lanjut dari penekanan strategi yang ditetapkan tidak dapat dilakukan karena tidak memiliki ukuran yang sama dengan kriteria keberhasilan yang ditetapkan. Ketidakseragaman ini menyebabkan penekanan strategi yang diarahkan menjadi tidak berfungsi optimal.

Masih dominannya budaya hierarchy pada sub peubah manajemen SDM dan penekanan strategi, serta peningkatan budaya adhorcracy pada sub peubah penekanan strategi yang tidak sejalan dengan sub peubah lainnya hendaknya menjadi perhatian agar seluruh kebijakan yang dibangun memiliki arah dan tujuan yang sama. Kebijakan juga hendaknya disesuaikan dengan kesiapan dan kondisi budaya organisasi secara keseluruhan. Dalam hal ini, penekanan strategi yang diarahkan untuk mengubah budaya menjadi inovatif tetap harus mempertimbangkan keselarasan pada sub peubah lainnya, sehingga hasil yang didapatkan lebih optimal. Penekanan strategi yang diarahkan pada budaya adhorcracy atau inovatif memang sejalan dengan konsep reformasi birokrasi, namun hal tersebut hendaknya diiringi dengan upaya peningkatan budaya adhorcracy pada aspek budaya organisasi lainnya.

\section{Kesimpulan}

Selama reformasi birokrasi, telah terjadi pergeseran budaya organisasi dari budaya hierarchy, yaitu budaya cenderung birokratis ke arah budaya market yang lebih berorientasi eksternal. Pergeseran tersebut menunjukkan bahwa budaya organisasi yang sebelumnya lebih menekankan pada terciptanya stabilitas dan kontrol telah bergeser menjadi budaya yang lebih mengutamakan pencapaian target, berorientasi 
hasil dan pemenuhan kebutuhan stakeholder. Pergeseran ini menunjuk-kan bahwa budaya organisasi telah bergerak ke arah yang sesuai dengan konsep NPM. Beberapa kebijakan reformasi birokrasi seperti kebijakan pemilihan kepemimpinan, rightsizing, dan survey kepuasan pelanggan merupakan beberapa faktor yang menjadi penyebab berubahnya budaya organisasi ke arah budaya market.

Namun, perubahan budaya organisasi tampak belum sepenuhnya optimal dan bahkan belum sepenuhnya kongruen. Berdasarkan hasil penelitian, terdapat dua faktor yang menjadi penyebab belum optimalnya perubahan budaya organisasi. Faktor pertama adalah terjadinya perbedaan persepsi terkait dengan pola karier yang lebih selektif dalam manajemen SDM. Beberapa pegawai menganggap aturan tersebut terlalu kaku dan menghambat pegawai. Faktor ini menunjukkan bahwa masih terdapat resistensi dari pegawai dalam organisasi. Peran kepempinan pada dasarnya sudah berorientasi eksternal merupakan faktor yang berperan untuk mengatasi kendala tersebut. Kemampuan manajerial khususnya pada pimpinan yang menjalankan fungsi manajemen SDM hendaknya perlu ditingkatkan. Pimpinan yang menjalankan fungsi manajemen SDM diupayakan mampu menciptakan strategi dan membangun komunikasi yang efektif dalam rangka menginternalisasi budaya yang diharapkan dalam organisasi.

Faktor kedua yang dimungkinkan menjadi kendala kurang optimalnya perubahan budaya organsiasi adalah kongruensi kebijakan perubahan yang ditetapkan. Sub peubah penekanan strategi yang cenderung mengalami kenaikan pada budaya adhorcracy sementara pada sub peubah budaya organisasi lain kenaikan terjadi pada budaya market merupakan indikasi bahwa kebijakan perubahan belum ditetapkan secara kongruen atau searah pada seluruh aspek dalam organisasi. Penetapan kebijakan tampaknya belum melihat kesiapan dan kesesuaian dengan kebijakan lain yang ditetapkan dalam organisasi. Ketidakseragaman dan ketidak-sesuaian tersebut menyebabkan perubahan yang diharapkan menjadi kurang optimal.

\section{Daftar Pustaka}

Aluko MAO. 2003. The impact of culture on organizational performance in selected textile firms in Nigeria. Nordic Journal of African Studies. 12(2): 164-179.

Asropi. 2008. Budaya inovasi dan reformasi birokrasi. Jurnal Ilmu Administrasi. 5(3): 246-255.

Brown K, Waterhouse J, Flynn C. 2003. Change management practices: is a hybrid model a better alternative for public sector agencies?. The International Journal of Public Sector Management. 16(3): 230-241.

Cameron KS, Quinn RE. 2011. Diagnosing and Changing Organizational Culture: based on the competing values framework. 3rd ed.. San Francisco (US): Jossey-Bass.

Carmeli A, Tishler A. 2004. The relationships between intagible organizational elements and organizational performance. Strategic Management Journal. 25: 1257-1278.DOI: 10.1002/smj.428.

[CIIA] Chartered Institute of Internal Auditor (US). 2014. What is Internal Audit? [internet]. [diunduh 2014 Juli 10]. Tersedia padahttps://www.iia.org.uk/aboutus/what-is-internal-audit/. 
Cole MS, Harris SG, Bernerth JB. 2006. Exploring the implications of vision, appropriateness, and execution of organizational change. Leadership \& Organization Development Journal. 27(5): 352-367.

Greasly K, Watson P, Patel S. 2008. The impact of organisational change on public sector employees implementing the UK government's "back to work" programme. Employee Relation. 31(4): 382-397.http://dx.doi.org/10.1108/ 01425450910965432.

Hendarto A. 2012. Relevansi New Public Management di Indonesia [internet]. [diunduh 2014 Juni 18]. Tersedia pada : http://www.academia.edu.

Hood C. 1991. A public management for all season?. Public Administration. 69(1): 3-19. DOI: 10.1111/j.1467-9299.1991.tb00779.x.

Hughes OE. 2003. Public Management and Administration : An Introduction. 3rd ed. New York (US): Palgrave Macmillan.

Jones LR, Kettl DF. 2004. Assessing public management reform strategy in an international context. Research in Public Policy Analysis and Management. 13: 453-473.

Larbi GA. 2003. The new public management approach and crisis states [discussion paper]. United Nations Research Institute for Social Development. 112: 1-60.

Muhammad F. 2008. Energizing Bureaucracy untuk Membangun Governance di Sektor Publik : Suatu Pemikiran Awal. Seminar Nasional Dies XV dan Temu Alumni MAP UGM; 2008 Agust 28; Yogyakarta, Indonesia. Yogyakarta (ID): 1-22.

Ojo O. 2010. Organisational culture and corporate performance: empirical evidence from Nigeria. Journal of Business System, Governance and Ethics. 5(2): 1-12.

Osborne D, Gaebler T. 1992. Mewirausahakan Birokrasi. Rosyid A, penerjemah. Jakarta (ID): Pustaka Binaman Pressindo. Terjemahan dari : Reinventing Goverment : how the entrepreneurial spirit is transforming the public sector.

Osborne D, Plastrik P. 1997. Memangkas Birokrasi: Lima Strategi Menuju Pemerintahan Wirausaha. Rosyid A, Ramelan, penerjemah. Jakarta (ID): PPM. Terjemahan dari : Banishing bureaucracy: the five strategies for reinventing goverment.

Parker R, Bradley L. 2001. Organisational culture in the public sector: evidence from 6 organisations. The International Journal of Public Sector Management. 13(2): 125-141.

Phookpan P. 2012. An analysis of organisational culture of integrated public organisations: the case of Thailand [disertasi]. Manchester (GB): Manchester Business School.

Prawirodirjo AS. 2007. Analisis pengaruh perubahan organisasi dan budaya organisasi terhadap kepuasan dan kinerja pegawai direktorat jenderal pajak (penelitian pada kantor pelayanan pajak berbasis administrasi modern di lingkungan kantor wilayah jakarta khusus) [tesis]. Jakarta (ID): Universitas Diponegoro.

Ramachandran SD. 2010. Organisational culture an exploratory study comparing faculties perspectives within public and private universities in Malaysia. International Journal of Educational Management. 25(6): 615-634 
Schraeder M, Tears RS, Jordan MH. 2005. Organizational culture in public sector organizations. Leadership \& Organizational Development Journal. 26(5/6): 492502.

Shahzad F, Luqman RA, Khan AR, Shabbir L. 2012. Impact of organizational culture on organizational performance: an overview. Interdisciplinary Journal of Conteporary Research in Business. 3(9): 975-985.

Simpson P, Beeby M. 1993. Facilitating public sector organisasional culture change through the process of transformational leadership. Management Education and Development. 24(4): 316-329.

Subagio R. 2012. Analisis penerapan reformasi birokrasi pada kantor pelayanan utama bea dan cukai tanjung priok [tesis]. Jakarta (ID): Universitas Indonesia.

Uddin MJ, Luva RH, Hossian SMM. 2013. Impact of organizational culture on employee performance and productivity: a case study of telecommunication sector in Bangladesh. International Journal of Business and Management. 8(2): 63-77. 